Abel, F. Feigl, P. Gross, H. von Halban, sen., $H$. Mark, F. A. Paneth and W. Pauli, sen.; the biochemists and biologists, F. Bergel, S. Jellinek, $O$. Loewi and L. Portheim. Others, like Hans Przibram, have died in concentration camps. Finally, Austria has been isolated from the democratic world and starved of literature other than Axis literature. So it may truly be said that the reconstruction of the Austrian universities will be a Herculean task.

It is gratifying to know that the first condition for the fulfilment of the task is being met by a purge of the schools of Nazis, carried out by the Provisional Government of the Republic. At the same time, instruction is reformed; for example, the teaching of languages-English and the Slav languages-is being extended, and para-military training has been abolished. Another encouraging feature is the energy with which the students are tackling the task of rebuilding the laboratories with their own hands.

Sir D'Arcy W. Thompson, the chairman of the meeting, recalled that some sixty years ago, a few years before the discovery of the $\mathrm{X}$-rays and of radioactivity, and before the development of quantum theory and the theory of relativity, it seemed to many that not much was left to be done in science. Sir D'Arcy forecast similar revolutions, and expressed his confidence that Austria, like other countries, would contribute to them. Among Austrian men of science of the past he singled out L. Boltzmann, who inaugurated a new era in physics, and is of particular interest to British men of scienee because of his association with Maxwell in more than one field. Prof. F. G. Donnan was hopeful that British, American and Soviet men of science will extend a helping hand. Among Austrian scientific workers he named specifically the older physicists, Doppler, Stefan, Loschmidt, Mach and, above all, Boltzmann ; the contemporary physicists, Stefan Meyer, K. Przibram, Schrödinger, Lise Meitner, Pauli; the chemists, Wegscheider, Abel, Paneth, Mark, K. H. Meyer, and the pioneers of micro-chemistry, Pregl, Emich and Feigl; the father of genetics, Mendel ; the founder of psychoanalysis, Freud.

Prof. L. Hogben dealt particularly with the devastating influence of pseudo-scientific racialism and said : "It is high time for someone to say, and to say on the housetops, that the moral horrors of the Belsen camp are the practical application, with a ruthlessness particularly Prussian, of a body of views, some of which are scientifically false, some entirely unproved, at best distortions of established truth impudently masquerading with the guise of biological science. I believe them to be false for reasons I set out as a professional biologist in my book 'Nature and Nurture' which appeared significantly before Hitler's rise to power. . . . I say significantly because such views are not confined to Nazi circles. They did not originate exclusively in Germany, though they there fell on receptive soil. They do not automatically die with the death of the Nazi regime. . . Because these views are still widely prevalent, because they are still a septic focus in the body politic, it is still necessary to refute them publicly wherever and whenever they find exponents. That is one of my reasons for participating in this gathering, not to emphasize what British science can do for Austria, but to suggest what the rebirth of Austrian science can contribute to a saner British outlook on man's social relations. For those who are rebuilding Austrian science have reason to recognize the malign consequences which Rassenhygiene or Eugenics, call it what you will, have left in their train; and I do not believe that you will lightly tolerate attempts to rehabilitate in the cap and gown of academic respectability an ideology which has brought untold misery to your country. ... During the past ten years there has been a Central European black-out of publications contributory to the advancement of intellectual freedom and civic enlightenment. . . . Might it not be at least a helpful gesture if a group of British scientific men who have played their part on the ideological front against the Nazi conspiracy against human freedom offered to make a first edition of their writings available for publication in Austria without monetary recompense as royalties? I do not think that our American colleagues would be slow to co-operate if we signified our will to do so."

Prof. P. M. S. Blackett, the last of the British speakers, paid tribute to Hess, who laid the basis of cosmic ray research, and expressed his pride in having had O. R. Frisch in his laboratory. He welcomed the idea of organizational union of academic and industrial men of science, as achieved in the Association of Austrian Chemists, Engineers and Scientific Workers in Great Britain and in the (British) Association of Scientific Workers. $\mathrm{He}_{e}$ stressed the necessity of equipping laboratories with up-to-date research tools, many of which are expensive ; in the liberated countries this will often be possible only with collaboration from outaide. Blackett specially supported plans for the exchange of personnel. Finally, Prof. K. Przibram, of the Radium Institute of the Vienna Academy of Sciences, who lived in Belgium during the German occupation, described the moral effects on men of science of intellectual isolation, and expressed Austria's desire to break this isolation as soon as possible.

At the end of the moeting it was announced that a committee of British men of science is being formed to implement suggestions for practical help. In particular, the committee will at the present stage concentrate on the question of the supply of literature.

E. Broda.

\section{HAMOGLOBIN LEVELS IN BRITAIN}

$\mathrm{T}$ HE Report of the Medical Research Council's Committee on Hæmoglobin Surveys*, entitled "Hæmoglobin Levels in Great Britain in 1943 (with Observations upon Serum Protein Levels)", is a valuable record of one aspect of national war-time health. The hæmoglobin level of some thirteen thousand adults (including seven hundred pregnant women) and some three thousand children were measured from the middle of the spring of 1943 until the middle of the autumn of that year. The HaldaneGowers method was used and its efficacy is discussed. Although the Committee does not consider this method ideal, it concludes that it was accurate enough to iustify the broad conclusions which are recorded in the 128 pages of this report, which is well illustrated by diagrams and graphs. The tech. nical evidence thus published cannot be summarized adequately here. The main conclusions, very briefly given, are as follows.

Severe grades of anxmia were rarely observed. Among men there was little difference, if any, between the hæmoglobin level of married and single men. In the age groups $20-49$ both showed a virtually

* Special Report Series, No. 252 (H.M. Stationery Office, 1945). 28. 
unchanging level (single men $103 \cdot 2$ per cent ; married men $102 \cdot 5$ per cent), with a slight fall at ages over 50. The mean level for men ( 102 per cent) was only a little below the mean level which was regarded as satisfactory before the War. In women, on the contrary, the mean level for both single and married women fell slightly during the later part of the age period 20-49 years, but rose again after 50 years of age. This fall and rise may be associated with menstruation and its cessation. The figures for married women up to the age of 60 were, however, roughly 2 per cent below those for single women. There was evidence which suggested that this difference may have been associated with child-bearing; the figures for women without children did not differ appreciably from those for single women. The average values for women were, moreover, considerably below those for men. At and abcve 60 years the fall for men and the rise for women made the curves converge. At every age below the menopause there was a small but consistent decline in the average hæmoglobin level as the number of pregnancies increased. This may have been directly due to parturition or indirectly to poorer nutrition of the mother as the family increases. As the Lancet (310, Sept. 8) says, women with families were not getting enough blood-forming foods and the children's ration was inadequate, so that the mother and father made it up with some of their rations. Serious anæmia in women was not, however, common. The report considers in some detail the relation between the hæmoglobin levels and the bearing of children.

Among young children of 2-5 years the incidence of anæmia was found to be unduly high; but we have little information about the hæmoglobin level of normal children. In general, the hæmoglobin levels of children rose from 1 to 7 years, altered little up to 10-11 years and then steadily rose to a maximum in boys of 16-19 years. In girls at the same ages the levels were 5-6 per cent lower. But both boys and girls had higher values than 'adults' under 20 years not at school, perhaps because the school ehildren who belong to the higher income groups are better fed.

Discussing the relation of hæmoglobin levels to occupations, the Committee found that these levels were high for men in the Civil Services, police (mostly Scotland Yard) and among students and male laboratory workers. Among women, they were high in the Civil Service and W.A.A.F. (mostly new entrants); they were lowest among textile workere and also low among nurses. The hæmoglobin levels of 990 Canadian soldiers serving in Great Britain showed a mean level 5 per cent higher than that of a comparable age group of British adult male civilians (excepting the medically selected Scotland Yard officials and the higher grades of the Civil Service).

The major causes of the low hæmoglobin levels in a group of adults studied was found to be iron deficiency, and the low level was removed by iron therapy.

On the whole, the hæmoglobin levels found were higher than those obtained in Aberdeen in 1935, but the Aberdeen subjects were unemployed or belonged to the lowest income groups. It is known that hæmoglobin levels vary with family income. Foods containing iron and other hæmopoietic substances, excepting cereals, are in the more expensive categories. The economic status of the present survey was higher than that of the Aberdeen studies, and no unemployed were included. An appreciable in. cidence of subnormal levels was, however, found; and the evidence suggested that these were due to a dietary deficiency, especially of iron. National flour has added $2 \mathrm{mgm}$. of iron per head per day to the diet of the working class and some $3 \mathrm{mgm}$. per head per day to schoolboy diet (adolescent schoolboys being among the largest eaters of national flour). At no time has the total amount of iron per.head per day been less than Sherman's most recent figure of normal requirements. Discussing the influence upon hæmoglobin levels of national flour, the Committee notes that protein and vitamin $\mathrm{C}$ are also needed for hæmoglobin synthesis. There has been an increase of animal protein purchased from $29 \cdot 3 \mathrm{gm}$. per head per day in 1941 to $33.2 \mathrm{gm}$. per head per day in 1943 and a slight increase in ascorbic acid. These increases may have helped to improve hæmoglobin levels. Bread is the main single source of iron for all classes except infants, but national flour contains more phytic acid than white bread and this renders iron less easily absorbable. On the other hand, increased phytic acid is accompanied by increase of phytase, so that the phytic acid increase may not be so deleterious as it seems to be.

Summing up, the Committee concludes that the hæmoglobin levels found during the four years of the War surveyed were reasonably good. We need, however, to raise the levels of certain groups, especially those of young children, pregnant women and people at the lower economic levels. Future surveys should employ standardized methods (which are discussed), personnel who are as free as possible from personal errors, and large enough groups; they should study the social background and food intake of the groups selected and also any other factors which influence the hæmoglobin levels.

\section{G. LApage.}

\section{FORTHCOMING EVENTS}

Saturday, January 12

ASSOCIATION OF BRITISH ZOOLOGISTS (at the Zoological Society of London, Regent's Park, London, N.W.8), at 10 a.m.-Eleventl Annual Meeting.

INSTITUTION OF MECHANICAL ENgINEERS, GRADUATES' SECTION (at Storey's Gate, St. James's Park, London, S.W.1), at 3.30 p.m.Mr. S. Sarwal: "Fuel Injection System on Diesel Engines".

\section{Monday, January 14}

Institution of EleCtrical ENGINeERS (at Savoy Place, Victoria Embankment, Iondon, W.C.2), at 5.30 p.m. -Discussion on "Country Road Lighting" (to be opened by Mr. C. R. Bicknell).

ASSOCIATION OF AUSTRIAN ENGINEERS, CHEMISTS AND SCIENTIFIC WORKERS IN GREAT BRITAIN (at the Austrian Centre, 69 Greencroft Gardens, London, N.W.6), at 7.15 p.m.-Dr. F. Singer : "Modern Ceramics".

\section{Tuesday, January 15}

ROYAL SOCIETY of ARTS, DOMINIONS AND Colonies SECtion (joint meeting with the INDIA AND BURMA SECTION, at John Adam Street, Adelphi, London, W.C.2), at 1.45 o.m.-Mr. G. Heaton Nicholls : "The Indians of South Africa".

EUGENICS SOCIETY (at the Royal Society, Burlington House, Piccadilly, London, W.1), at 5.30 p.m.--Dr. Eliot T. Slater: "An Investigation into Assortative Mating"; Mrs. Moya Woodside : "Courtship and Mating in an Urban Community".

MANCHESTER LITERARY AND PHILOSOPHICAL SOCIETY (in the

Reynolds Hall, College of Technology, Manchester), at 5.30 p.m.Dr. B. Ifor Evans: "The Relationship of the Arts".

ROYAL ANTHROPOLOGICAL INSTITUTE (at 21 Bedford Square, London, W.C.X), at 5.30 p.m.-Dr. Leopold Stein : "Notes on the Natural History of Speech".

Royal Photographic Society, SCIENTIFic and TeChNical Group (at 16 Prince's Gate, London, S.W.7), at 6 p.m.-Mr. E. W. H. Selwyn: "How it Works in Phctography", No. 3: "Grain and Resolution".

\section{Wednesday, January 16}

ROYAL SOCIETY OF ARTS (at John Adam Street, Adelphi, London, W.C.2), at 1.45 p.m.- Sir Jack Drummond, F.R.S.: "Famine Conditions and Mal-Nutrition in Europe".

GEOLOGICAI SOCIETY OF LONDON (at Burlington House, Piceadilly, London, W.1), at 5 p.m.- Scientific Papers. 